\title{
Indelible ink
}

\section{Mr. M. Braconnot}

To cite this article: Mr. M. Braconnot (1829) Indelible ink, Philosophical Magazine Series 2, 6:32, 141-142, DOI: $10.1080 / 14786442908675085$

To link to this article: http://dx.doi.org/10.1080/14786442908675085

$$
\text { 册Published online: } 14 \text { Jul } 2009 .
$$

Submit your article to this journal 준

Шll Article views: 1

Q View related articles ¿ 
the dyeing of wool by means of Prussian blue;-M. Boyer gave a favourable report also respecting $M$. Delpech's paper on the Resection of the lower jaw.-M. Moreau de Jonnès continued the reading of his memoir on geographical botany. -The Academy; in a secret committee, agreed to the dedication of $M$. Brué's new geographical atlas.

Sept. 8.-M. Baudelocque, nephew, announced two new processes in uterine hæmorrhages and affections of the womb.--M. Marc Jadot sent a geographical table containing the laws of the population of France and of the city of Paris.-M. Say sent some reflections on the relations of the exact sciences with political aconomy.-M. Chevreul read a memoir on the fatty matter of wool.-M. Geoffroy Saint-Hilaire read considerations on the vision of the mole.-M. Mirbel gave a verbal account of the first Number of MM. Durville and Lesson's work on cryptogamous plants.

Sept. 15.-Several letters were read from MM. Durville, Quoy, and Gaymard. These travellers annonnced a great number of drawings and descriptions of animals.- $M$. Cuvier read a favourable report respecting the experiments of $M$. Flourens.-M. Maurice gave a favourable account of $M$. Liouville's memoir, on dynamic electricity in general, and particularly on the mutual action of the pole of the magnet and a conducting wire.-M. Sérullas read a memoir On the action of sulphuric acid on alcohol, and the resulting products.

\section{Intelligence and Miscellaneous Articles.}

DECEASE OF DR. YOUNG AND SIR HUMPHRY DAVY. T $T$ is our melancholy duty to record the loss of two of our most 1 distinguished cultivators of science, Dr.Thomas Young, and Sir Humphry Davy: Dr. Young died in London on May 10th, and Sir H. Davy, at Geneva, on May 29th. The most important of the discoveries and contributions to science of both, have been from time to time recorded or inserted in the Philosophical Magazine; and we have commenced the present Number with the last production of Sir H. Davy, A paper on the Electricity of the Torpedo.

SPONGY PLATINA.

M. Pleischel recommends that a piece of paper be imbibed three times in succession with a solution of muriate of platina, and then burnt. The residue is the platina, he says, in its best state for effecting ignition. We have always found that, when prepared by heating a little pure ammonio-muriate of platina upon platina foil in a spiritlamp, at a temperature as low as possible, so that it be sufficient to dissipate every thing volatile, then the platina would inflame a mixture of oxygen and hydrogen at the lowest possible temperature. -Royal Instit. Journal, April 1829.

INDELIBLE INK : BY M. BRACONNOT.

Dissolve 20 grammes of Dantzic potash in a sufficient quantity of boiling water, add 10 grammes of animal matter, such as the parings 
of tanned skins, and 5 grammes of flower of sulphur; boil the whole to dryness in a cast iron vessel ; afterwards heat the matter strungly and stir it continually until it softens, taking care that it does not burn; then baving gradually added a small quantity of water, filter it through a coarse cloth. A deep coloured liquor runs through, which may be kept for any length of time in a bottle, but it must be, kept well corked; a single pen-full of this ink is sufficient to write one or two quarto pages, and it possesses all the properties which can be expected in an indestructible ink ; it flows much better than common ink, and does not clog the pen by any substances held in suspension; it also resists the most powerful chemical agents, as.will presently appear.

A trtrp of paper written upon,with this solution,. was treated with a boiling solution of potash, and was alnost entirely destroyed; but the portions of paper remaining undestroyed, exhibited the writing perfectly. Paper written upon with the same solution, immersed for an instant in moderately strong sulphuric acid, was partly dissolved, being converted into a glutinous substance; but upon the undissolved portions, though rendered very thin, the writing remained legible.

Concentrated nitric acid had no effect upon writing with this ink in twenty-four hours, at a temperature below that for the complete destruction of the paper.

Another piece of paper written upon with the same ink, was immersed for some time in a strong solution of cbloride of lime, mixed with muriatic acid, and it was afterwards put into a solution of potash for twenty-four hours; after this it was boiled to dryness, and then dissolved in water, when only a small portion of paper remained, but upon this the letters were very distinct.

M. Braconnot is of opinion that this solution may be advantageously employed in dyeing chesnut browns upon cotton, linen, and silk, or for.darkening other colours.-Annales de Chim. et de Phys. Feb. 1829.

M. Braconnot has published a notice in the Annales de Chimie for April, in which he states that this ink is not so indestructible as he at first imagined, for it was destroyed by successive digestions in chlorine and potash.

PREPARATION AND COMPOSITION OF SOME BROMIDES, BY

M. HENRY, JUN.

PERBROMIDE OF IRON.

Take a quantity of pure bromine, and put it into a porcelain cap. sule, containing about twenty times its weight of distilled water, and add gradually, and stirring with a brass rod, iron filings until the liquor ceases to emit bubbles; it is then to be gently heated, and when it has acquired a greenish tint, it is to be filtered. The solution contains protobromide of iron, which is precipitated white by potash like the protosalts of iron, emitting a very peculiar smell; then evaporate to dryness by exposure to the air. The residual mass is of an orange red colour; treated with water it does not entirely dissolve, there remain some portions of peroxide of iron 